\title{
Becoming an Immigrant? Border Harms and "British" Men with Previous Convictions in British Immigration Removal Centers
}

\section{Dan Godshaw ${ }^{1}$}

Published online: 8 August 2020

(C) The Author(s) 2020

\begin{abstract}
In the context of heightened debate around increasingly hostile immigration policies, the detention and deportation of people with long-standing connections to the United Kingdom (UK) have, within the last few years, received public attention. Such individualspeople who were born in or came to the UK as children-make up a significant proportion of the "foreign criminal" population in detention. This article examines how those individuals with long-standing links, who also have criminal convictions, are often "erased" by the British state. Drawing on qualitative fieldwork with men currently and formerly held in immigration removal centers, I argue that institutional failings in immigration and local authority care "guide" some who grow up in the UK toward (and into) the criminal justice system. Shunning responsibility for these failings, the British state enacts a further punishment through immigration detention and attempted deportation. Despite acts that resist and problematize foreignness, detained "Brits" experience specific harms that change the way they feel about identity and belonging in Britain. These processes highlight the ways that national identity and immigration status intersect with class, gender and race to produce traumatic experiences of cultural denationalization.
\end{abstract}

\section{Introduction}

We are prisoners in a land we've been in for most of our lives. This is my country. How can you tell me that it's not? I was in this country when the queen mother died, when we invaded Iraq, when the Twin Towers came down, when Obama came to power... I remember penny sweets, ticket inspectors on the back of buses, the Millennium Dome being built. What are they talking about when they say I'm not British? They expect you to wipe your history. How? [Anthony, who came to the United Kingdom at age eight]

I think it is very odd to have people who identify in virtually every way as British and then say to them we're going to remove you from the country... I routinely come

Dan Godshaw

dan.godshaw@bristol.ac.uk

1 School of Sociology, Politics and International Studies, University of Bristol, Bristol, UK 
across people who have been in this country since a very young age and simply don't understand what's going on in the countries they're about to be removed to. That just feels wrong. It feels counterproductive, it feels unjust. [Hindpal Singh Bhui, Her Majesty's Inspectorate of Prisons]

With eleven Immigration Removal Centers (IRCs) in operation across the United Kingdom (UK) when fieldwork was conducted for this article, the UK has one of the largest immigration detention estates in Europe and, until it announced its departure from the European Union (EU), was the only member to detain "non-citizens" indefinitely in closed, prison-like conditions. The rapid expansion of detention capacity in the UK has coincided with moral panics about deceptive, "bogus" asylum seekers (since the late 1990s) and dangerous "foreign criminals" (since 2006) (B. Anderson 2013). Academics and practitioners have documented an array of border harms that the state's extensive use of detention, mediated through the private subcontractors that manage the IRCs, inflicts on those held. These include abjection and deprivation of rights (Hall 2012; Tyler 2013), exploitative labor (Bales and Mayblin 2018), abuse and neglect (Shaw 2018), isolation and alienation (Bosworth 2014, 2018), severe mental health problems, traumatization and self-harm (Athwal 2015; Neale 2012; Tsangarides 2012), limited access to adequate legal support (CapeDavenhill 2015), and uncertainty and indefiniteness (Griffiths 2013, 2014).

In mid-2019, in the midst of increased public scrutiny of the UK government's "hostile environment" immigration strategy, a cross-party group of parliamentarians tabled amendments to the Immigration and Social Security Co-Ordination (EU Withdrawal) Bill 2017-2019, which included a twenty-eight-day time limit on detention. It seemed unlikely, however, that the proposed time limit would apply to people with previous convictions because it explicitly excluded those detained "in the interests of national security" (Parliament 2019: 3), reflecting a long-standing tendency for campaigners to "accept the mythical distinction between Good and Bad Migrants" (Griffiths 2017: 531). Unwillingness to extend a potential time limit to former "Foreign National Offenders" (FNOs) persists, despite findings in a report commissioned by the Home Office that this group spends the longest periods in detention and thus are among those most harmed by the absence of a time limit (Shaw 2016: 93). In the last few years, it has also been established that people who came to the UK as children comprise a significant proportion of the ex-FNOs, who often spend months and sometimes years in IRCs. Attention has been drawn to their situation in the media (Haque 2019), by NGOs (Godshaw 2017: 28; Phelps et al. 2014), and by hunger strikers detained at Yarl's Wood IRC, who demanded "an end to the exiling of those who came as children and are culturally British" (Detained Voices 2018). In his follow-up report for the Home Office on the detention of vulnerable people, former Prisons and Probation Ombudsman Stephen Shaw (2018: 90) recommended that the government should "no longer routinely seek to remove those who were born in the UK or have been brought up here from an early age." People who grew up in the UK, however, continue to be detained and deported to places that feel foreign.

This article focuses on adult men with experience of detention who were granted secure immigration status as children (along with their families) and who subsequently had this status revoked with a deportation order. I draw on qualitative data from fifteen months of fieldwork undertaken inside and outside several $\mathrm{IRCs}^{1}$ between 2017 and 2018 and is

\footnotetext{
1 The full dataset includes semi-structured and life history interviews, IRC visits, observations of immigration hearings and document analysis with twenty-four men with experience of detention, as well as interviews with twenty practitioners including civil servants, NGO workers, solicitors, a social worker and a parliamentarian. I approached government ministers, Home Office officials and IRC directors, but they refused to be interviewed. Interviews that took place outside detention were recorded and then transcribed,
} 
informed, in particular, by an eight-month stint ${ }^{2}$ as a support worker and researcher at Gatwick Detainees Welfare Group (GDWG) - an NGO that supports detainees in Brook House and Tinsley House IRCs and campaigns for changes to the detention system. Interlocutors were recruited through IRC visitors' groups, from my personal networks, and through "snowballing," enabling a range of perspectives from across the detention estate. Many, if not all, people who have been detained have specific vulnerabilities due to their experience of indefinite incarceration, ongoing immigration cases and previous traumas. In keeping with methodologies that stress that an ethical baseline of “'do no harm' is not [always] enough" (Hugman et al. 2011), I developed an extensive ethical framework that included carefully ensuring confidentiality and working closely with gatekeepers to identify and provide practical and emotional support to participants. I also designed a multistage consent process and worked with participants over several months, enabling me to build trusting relationships as well as recasting informed consent as a meaningful process, rather than a one-off event.

Case studies included in this article are drawn from eight participants who arrived in the UK between the ages of five and fifteen and one participant who was born in the UK, all of whom were granted permanent residency as dependents. ${ }^{3}$ This is not to suggest that others in detention, such as women in the same situation, former unaccompanied asylum-seeking minors, ${ }^{4}$ and people who have spent many years in the UK but who arrived in the UK as adults, do not also feel strong feelings of belonging to the UK or do not have similar experiences of immigration controls. Neither do I contend that suffering is a zero-sum game, with this group being the worst off in the UK immigration system; detention is harmful for the majority of those held there, regardless of their background or immigration history.

Rather, building on recent academic work that is beginning to explore the issue in the wider contexts of citizenship and penality (Bosworth 2014; Bosworth and Slade 2014; Griffiths 2017; Turnbull and Hasselberg 2017), this article narrows the discussion and traces routes to, and experiences of, detention for men who grew up in the UK and who become detainable "foreign criminals." Aided by data selected systematically using reflexive thematic coding, which enabled careful, inductive analysis, as well as being informed by the existing literature, I argue that these individuals face unacknowledged structural barriers located primarily in state policy and practice that effectively guide them toward the breaking of social rules and subsequent deportation orders. Instead of providing redress for the social and institutional failings that lead to criminality and imprisonment, the state enacts a further and far more grave form of punishment through immigration detention and attempted deportation. Despite acts that resist and problematize their new "foreignness"

\footnotetext{
Footnote 1 (continued)

but because recording devices are banned inside IRCs, research encounters there were documented through note-taking during and immediately after visits.

2 As part of this role, I produced a report (Godshaw 2017) with recommendations for government, local authorities and support services. This article includes data from the report and extends its findings.

3 These participants had an average arrival age of eight and had lived in the UK for an average of 23 years. All are referred to in this article by pseudonyms to protect their identities.

${ }^{4}$ Elsewhere, I have argued that former unaccompanied asylum-seeking minors follow similar life trajectories and experience comparable border harms to people who obtained status as dependents and thus could be thought about collectively as "young arrivers" (Godshaw 2017).
} 
in detention and assert "Britishness," they experience specific harms while detained that are tied intimately to their immigration histories and that change the way they feel about identity and belonging in Britain. To explore these processes through the most frequently discussed themes that emerged during coding, I turn first to shared stories of trauma, social exclusion and local authority care in childhood and second to the eventual production of detainability via the criminal justice system. Third, I examine the experience of detention as a dramatic rupture in lives and identities, and finally, I show how people often respond to this rupture by refusing to comply with the deportation regime in ways linked to their lives in Britain, intensifying the array of specific and punitive border harms to which this group is exposed. Importantly, their "carceral trajectories" (Turnbull and Hasselberg 2017), as well as the harms they experience while detained, highlight the ways that national identity and immigration status intersect with class, gender and race to produce traumatic experiences of cultural denationalization in the "hostile environment."

\section{Traumatic Trajectories, Social Exclusion and Local Authority Care}

There are a number of routes through which children without British citizenship may arrive in the UK. These include family reunification or temporary visas, undocumented migration, or birth in the UK, where neither parent has citizenship or settled immigration status. NGO research has found that children who are not citizens may face significant difficulties including trauma, barriers to making immigration and citizenship claims, reduced access to education and health care, poverty, and increased likelihood of entering the care system (Dorling 2013; Garin et al. 2016). The rights and entitlements of non-citizen children are nonetheless generally more extensive than those of adults, most notably through the Section 55 of the Borders, Citizenship and Immigration Act 2009, which extended the protections of the United Nations Convention on the Rights of the Child (1989) to children without citizenship. Although this legislation does not always protect the interests of "foreign" children (Wilding and Dembour 2015), it is now far less likely that they will be detained or deported than adults.

For most participants in my study, significant traumatic events characterized early childhood and haunted them throughout their lives. Often, this began with gang violence, genocide or war, and included the killing or attempted killing of close family members. For several participants, the murder of a parent or sibling preceded immigration to the UK, and it was common for them to describe these events as being deeply traumatizing, leading to stress, behavioral problems, and difficulties adapting to life in the UK. For Suleymaan, his father's death in Somalia and perceived abandonment by his mother, who had left her children to escape to the UK, led to persistent feelings of anger and blame after he was reunited with her in Britain at age thirteen, causing him to rebel and reject parental guidance. Several participants were later diagnosed with post-traumatic stress disorder (PTSD) and other mental health problems linked to their experiences in early life. Reflecting structurally racist patterns of disbelief, misdiagnosis, and perceptions of fear toward people from ethnic minority communities with mental health issues in the UK, particularly for young black men (Keating and Robertson 2004), these problems were often not identified by health services, meaning that the effects of trauma were often untreated and dismissed as bad behavior. Dalmar, who had escaped the Somalia civil war, expressed to me that "I just wish that someone had picked this up when I was a kid and given me support and treatment." Even when PTSD was diagnosed in adulthood, immigration decision letters to participants 
showed that the Home Office continually failed to acknowledge the well-documented links between untreated trauma and "deviant" behavior (Allen 2008).

It is well established that immigration often entails downward shifts in social mobility, and this was acutely visible in the stories of my participants, most of whom grew up in poverty on deprived, inner-city council estates in asylum accommodation that they were "dispersed" to by the state with caregivers who were prevented from working for several years while their immigration claims were being processed. The combination of trauma with the cultural upheaval of immigration, racialization and social deprivation led to behavioral problems at school, exclusion, and disengagement with education, increasing the likelihood of criminal offending in identical ways to their citizen peers who grew up in similar circumstances (Anderson et al. 2005). Furthermore, while children without British citizenship are entitled to register as citizens after ten years of continuous residence, ${ }^{5}$ the intersection of class and race with immigration status and austerity means that caregivers often lack the education, legal support and financial resources to make complicated and expensive citizenship applications for children, ${ }^{6}$ thereby entrenching their categorical status as "immigrants," as opposed to citizens who belong, and leaving them unprotected from deportation as adults.

For some who arrive in the UK as children and who later end up in detention, trauma continues after arrival in the form of abuse and neglect from caregivers. Anthony, C-Five and Dalmar were taken into the care of the state through the local authority "looked-after children" system, where they experienced three failings in care that set them on an almost unavoidable path to deportability. First, placement in children's homes with other traumatized children, as well as excessive movement between them and a lack of compassionate supervision, compounded behavioral problems and caused severe disruption to education. C-Five, who arrived at age ten and who was taken into care when he was thirteen, following physical abuse from his father, explained:

I didn't have anyone guiding me... They didn't prepare me for life ... I had to travel between care homes, so I didn't finish my [high school graduation] ... They mixed us with kids who were getting sexually abused or had big anger issues. There were alcoholics and drug abusers ... So what am I going to learn? What I'm seeing!

Second, the lack of stability and guidance that participants experienced in care extended to their citizenship status, with dire consequences for them later in life. No one I spoke with was informed by his caregivers of the importance of registering for citizenship, and no one received funding for or assistance with making an application. A social worker that I interviewed explained that this was a result of high caseloads and limited resources, and a representative from Project for the Registration as Children as British Citizens (PRCBC), an NGO that offers legal advice and representation, told me that social workers usually knew very little about the need for or process of registering children in their care. Anthony, who arrived at age eight, was also abused by his father and taken into care when he was 11 years old. He made a direct link between these failures and becoming deportable:

\footnotetext{
5 Registration is subject to meeting the "good character requirement," criticized by the Project for the Registration as Children as British Citizens (PRCBC) (2019) for unfairly blocking children's access to citizenship and because the requirement disproportionately affects children from ethnic minority backgrounds in care.

6 Applications often require assistance from legal professionals and cost applicants nearly $£ 1000$ despite costing the Home Office less than $£ 400$ to process (PRCBC 2017).
} 
Social services are the main reason I'm [in detention] ... if they didn't just see me as caseload, if they saw me as a person instead, all of this could have been avoided with one thing — getting me a passport ... the actual care was bad enough, but not doing that was even worse.

Reflecting scholarly work on links between care and subsequent offending (Hayden 2010; Staines 2017), a recent NGO report found that children who had been in residential care were criminalized at disproportionately higher rates in comparison with other children and that a central mechanism for this is that staff from children's homes regularly call police to deal with minor incidents (Sands 2016). This practice was the third failure observed in local authority care, which all three looked-after participants, already with behavioral issues as a result of their unacknowledged trauma, experienced. Contact with police began a downward spiral of criminalization that had dire consequences in adulthood when citizenship had not been secured. Anthony, for example, tallied twenty convictions for minor incidents that happened in children's homes after staff called the police, including property destruction, fighting with peers and spitting. He made a direct link between care and criminality:

My criminal history started in care. You smash up your room and get arrested for criminal damage. You spit at police and get arrested for assaulting a police officer. You scrap with a friend and get arrested for assault. All of my convictions happened in care. If I was at home with my family, I would never have been arrested for these things.

In sum, many who arrived in the UK as children are traumatized and socially excluded as children, which creates barriers to making citizenship applications. Being taken into care makes it even more unlikely that registrations for citizenship will be made and increases the likelihood of criminalization. The British state often fails to acknowledge its role in these processes that can lead directly to contact with the criminal justice system, cementing deportability once they become adults.

\section{Becoming Detainable: "Foreign Criminals" in the Criminal Justice System}

A recent report by Member of Parliament (MP) David Lammy (2017) found that that Black, Asian and minority ethnic (BAME) people, particularly men, were significantly overrepresented in the main pathways to the criminal justice system, which included poverty, school exclusion, contact with the care and mental health systems, and stop and searches (see also Phillips and Bowling 2017). Linking these processes to immigration status, Griffiths (2017: 541) has argued that male "foreign criminals" become positioned as "folk devils" in the UK at the "intersection of multiple denigrated identities, in which ethnicity, nationality, immigration status, gender and 'deviant' behavior converge and intensify" (see also Bowling and Westenra 2020; de Noronha 2019). It was unsurprising, therefore, that everyone I met in detention who grew up in the UK was from working-class, BAME backgrounds. Disadvantaged and demonized by their classed, gendered and racialized positions, contact with the criminal justice system triggered deportation orders for men without citizenship. ${ }^{7}$

\footnotetext{
7 Under the UK Borders Act 2007, if a non-citizen adult is given a prison sentence of twelve months or more (twenty-four months for EU nationals), he/she is issued with an automatic deportation order along with a revocation of immigration status.
} 
Participants cited two central injustices with the way that they became detainable through the criminal justice system.

First, men who grew up in the UK lacked knowledge about the consequences of offending and said that they were not given warnings that they could face deportation. Many participants stated that they had always thought that they were British citizens or else assumed that their permanent residency status was irrevocable. They complained that had they known that prison sentences could lead to deportation, through publicity campaigns or through direct warnings from the police or Home Office, they would have been better placed to avoid trouble. The state thus "only lets you know when it's already too late" (Christopher). For Lee, deportation proceedings were initiated in a particularly sudden and unforeseeable way after he was arrested under Operation Nexus, an opaque joint Home Office and police mechanism which enables people to be found responsible for criminal behavior despite not having been convicted by a criminal court. ${ }^{8}$ In his words, "[t]he Home Office revoked my refugee status, took me to Colnbrook [IRC] and gave me removal directions. It was done so quick. I was shocked. There was no warning."

Second, and importantly, men who were raised in the UK regard their offending as inextricably tied to growing up in the UK. All but one participant came into contact with the police through criminal damage, drugs and theft offenses that began when they were young teenagers and took place in and around the estates and children's homes where they lived and where "people sold drugs and got into trouble" (Ahmed). These offenses tended to culminate in more serious charges that led to prison sentences of more than twelve months. Ahmed, who went to prison for fighting during a breakdown following his father's death, stressed that "I'm a product of this environment," and Anthony, who served his first sentence at age seventeen for a stealing a wallet after social services left him on the streets with no money, and his second for participating in the 2011 London Riots, argued: "People like me shouldn't be here [...] we are not foreign criminals. We're homegrown criminals. I learnt all of my behavior from this country."

Respondents were deeply frustrated by the treatment that they received in comparison to that of their peers, who had British citizenship and came from the same estates and children's homes. Already likely to receive and serve longer sentences than those with citizenship for identical offenses (Bhui 2007; Griffiths 2017; Turnbull and Hasselberg 2017), "foreign criminals" receive automatic deportation orders instead of release, are often kept in prison after they have completed their sentences, and are usually then transferred to immigration detention. Dalmar, for example, was detained on release from prison after serving nearly ten years of an indeterminate sentence for punching a man on the street and stealing his iPod. Rather than viewing his traumatic childhood and subsequent PTSD diagnosis as mitigating factors, the Parole Board claimed that this could affect behavior and thus justified continued imprisonment. Moreover, in contrast to their public image as irredeemable "folk devils," many participants spoke about their commitment to the rehabilitative path of prison life, completing courses and programs that made them feel included in the spirit of the British justice system and that they expected to prepare them for life in Britain after release. Upon completion of sentences, however, rather than the "second chances" (as OJ put it) and continued rehabilitative support that their fellow former inmates received, they

\footnotetext{
${ }^{8}$ For more on Operation Nexus, see Griffiths (2017) and Parmar (2018).
} 
felt that they were forgotten and left to languish in immigration detention by probation services despite their perceived equivalence as homegrown criminals.

Routes to detention for people who grew up in the UK thus followed similar trajectories to their working-class, BAME citizen peers. The intersection of structural disadvantages with immigration and citizenship status mean that this group is demonized by the state, despite often having no awareness that contact with the police could have dire consequences. Bhui (2016) has argued that treatment of FNOs operates within a system of "racialized border control" in Britain, in which poorer people from ethnic minorities are disproportionately detained and a conception of Britishness based on race and exclusion is delineated. For people who were raised in the UK, being detained triggered acute awareness of the exclusionary dimensions of national belonging and led to dramatic reconfigurations of their sense of Britishness.

\section{Becoming an Immigrant? A Biographical Rupture for Brits in Detention}

According to Home Office data, just under a third of the 27,000 people detained every year arrive in detention as a result of contact with the criminal justice system (Shaw 2018: 26). I was unable to produce an estimate for the proportion who arrived as children because neither visitors' groups nor the Home Office collect data on the age at which detainees enter the UK. Anecdotally, however, several key informants told me that they came across people from this group regularly in detention, and this reflected my experience of case working inside Brook House IRC. Given these observations, alongside Shaw's (2018: 89) assertation that "a significant proportion of those deemed FNOs had grown up in the UK," it would be reasonable to approximate that hundreds, if not thousands, of people who fit this category are detained every year.

National identity is not synonymous with or reducible to citizenship status. Rather, national identity is underpinned by and constructed through the less tangible concepts of imagination, values and relational questions of legitimacy (B.R.O. Anderson 1983; B. Anderson 2013). Indeed, when non-citizen men who grew up in the UK arrive in IRCs, they perceive themselves, and are perceived by others, to be British. As one worker at the NGO, Verne Visitors, stressed, they "don't see themselves as migrants." Despite the previously mentioned difficulties settling into life in the UK, non-citizen men went to school and college in Britain and most have worked and paid taxes for many years. They speak with local, working-class accents, and would be indistinguishable from their British peers had they not been locked up in IRCs. They have extensive networks of family and friends in the UK and often have children, partners and other close relatives who depend on them for support. As Anthony's statement at the beginning of this article alludes to, they express, regardless of their country of origin or context of arrival, a sense of deeply rooted and enduring connection to the UK as home and as a central part of their identity. Ahmed, for example, who arrived in the UK when he was nine and grew up in a white, working-class neighborhood, stressed to me that he was "westernized," and that he had been fully accepted into his local community as "one of them" despite it being a "rough, racist area." He talked about his diehard support of the Queens Park Rangers Football Club and his years of paying taxes as an electrician, adding that a typical evening would involve an Indian takeaway meal and watching EastEnders after work like his British "mates." As with other participants, as far as Ahmed was concerned, he had always been British: "[When I came to the UK] I loved it .... I 
don't know anywhere else .... I was raised here, brought up in this culture .... Britain is home and I always felt British."

That these feelings of and appeals to national identity were not enough to protect participants from potential expulsion reveals the "raceful" implications of immigration and citizenship policy in the UK, connected to imagined histories of ancestry and ultimately excluding Ahmed and others from the ranks of "good citizen" despite participation in the British "community of value" (B. Anderson 2013: 46, 178). In her analysis of "closed circuits" of illegalized life for undocumented French youths, Boe (2016: 321) has argued that while prison is usually a manageable experience marked by continuity with growing up in marginalized neighborhoods, being detained triggers a "brutal biographical rupture," characterized by feelings of banishment and reconfigurations of identity. Indeed, one of the most profound impacts of being detained for people who grew up in the UK is an existential sense of shock, which shatters previously taken-forgranted certainties and feelings of belonging to British society. For many, this process begins in prison when they realize that they will not be going home after their sentence expires. Many participants told me that they had no idea that they could be detained and assumed that prison staff were either mistaken or joking. As Christopher put it,

I was upset, angry, frustrated and confused .... I thought they'd made a mistake .... On the day my sentence ended I waited for them to come and release me. After 3 days they still didn't come, and I realized they were telling the truth.

Consistent with theoretical work on immigration controls and sovereignty (see, e.g., Cornelisse 2010), this sense of disbelief is perhaps rooted in the tension between the systematic use of border mechanisms by modern states that link territory to rights, despite vociferous celebrations of universal human rights, and that continue after arrival in immigration detention. As a solicitor explained to me, "the sense that they could be deported doesn't really sink in [and] they think that they'll be out soon," making it difficult for legal representatives and support organizations to work meaningfully with them. When the severity of the situation becomes clear, however, men who grew up in the UK report periods of intense stress and physiological symptoms such as insomnia, inability to eat, and heart palpitations. One participant attempted suicide soon after being detained when he realized that the country that raised him had turned its back on him.

Once the shock of detention and the stress of grasping the situation subsides, strong feelings of anger about being treated differently than those with British citizenship take over (see also Parmar 2018). Being detained begins to act as a challenge to national and cultural affiliations of belonging and disregards socialization into and contributions toward the UK. As well as emphasizing integration into the UK in life narratives, as demonstrated above, some people from this group found solace in building positive relationships with British officers, echoing Bosworth and Slade's (2014: 174) observation that detainees who have grown up in the UK "attempt to assert a status as a kind of equivalent citizen" in their search for recognition. Lee argued that he was able to get along with younger officers because they generally did not have an ideological commitment to detention and were "just like the girl you went to school with." As in Bosworth's (2014: 98) extensive study of British IRCs, my conversations with officers showed that they responded to these bonds by making clear distinctions between recent arrivals and people who came to the UK as children, struggling to conceive of them as not being British. For Ahmed, these relational experiences enabled him to move beyond equivalence and claim a higher stake in British identity than IRC staff: "The officers became my friends. They treated me with respect and shared their food with me.... I 
told them look, I'm more British than you. I've been here, I've been British since before you were born."

In detention, where people often associate with others from similar cultural, ethnic, national or religious backgrounds (Bosworth 2014: 140), another common response to challenged identity is to build friendships with other detainees who are perceived as British, establishing a sense of collective solidarity and identity. Despite their diverse backgrounds, when describing everyday life in detention, participants spoke frequently about themselves and their friends in detention as Brits and in contrast to others who were labeled as "freshies," "different" and "backwards," even when they were born in the same country. Anthony explained that "people who have been here a really long time, British people, we stick together," and Lee told me about the apparently naturalness of this process:

You've got everyone from different cultures .... You get one out of ten that will hang around with us, not with his own people.... They were raised more in the English culture .... "Oh I'm from Peckham, oh yeh yeh I'm from New Cross!" You're just talking normal, you just get on.

Despite these convincing attempts to emphasize Britishness as a cultural identity through "acts of citizenship" (Isin and Nielson 2008) that go beyond legal status, the frustration that detainees who were raised in the UK feel often decreases their sense of belonging in Britain and changes the way they view the society in which they grew up. For many, this new and profound sense of exclusion manifests in an acute awareness of institutional racism. For example, several participants said that being detained represented a more significant experience of discrimination based on their heritage compared to encounters with the criminal justice and judicial systems. Furthermore, there was general agreement that a small proportion of detention officers expressed racism and xenophobia in occasionally overt, ${ }^{9}$ but usually covert ways often articulated through subtle provocations, body language and "the way they look down on you" (Suleymaan). Over time, detention and perceived racism caused people who felt British — and who were perceived by others in detention to be British - to become unwanted immigrants, omitted from the emotional dimensions and material benefits of national belonging. As Griffiths (2017: 541) has argued in relation to ex-FNOs, in general, they are expected not only to acquiesce to forms of control but also to inwardly adopt this submission in a process "reminiscent, in many ways, of the internalization of imposed colonial identities." Those who grew up in the UK thus experience, in effect, a form of cultural banishment or "denationalization" (Gibney 2020) of the self. Rather than border controls being simply about managing the mobility of non-citizens, then, immigration detention becomes a constitutive "technology of citizenship" itself (Walters 2002: 267), able both to delineate (bad) migrants from (good) citizens and, in this case, transform psychological perceptions of national belonging. In the words of two participants:

Now I feel Congolese because I'm not wanted here. I'm hanging here by a thread. [Lee]

When I got detained, I felt different to my own brothers and sisters.... Now I feel like an immigrant. [Ahmed]

${ }^{9}$ See Plomin (2017) for more on racist abuse in Brook House IRC. 
Detained men who grew up in Britain thus experience and enact Britishness through a range of cultural signifiers. Being detained leads to a dramatic rupture in the life course that reconfigures relational identities. Despite responses that problematize challenges to Britishness, coming face to face with the reality of the exclusionary, racialized borders of Britishness caused people who once belonged to begin to internalize unwanted immigrant identities.

\section{Non-compliance and the Punitive Harms of Detention for Men Who Grew up in the UK}

A major consequence of ruptured identities for men who grew up in Britain is a unique and paradoxical positioning between legitimacy and illegitimacy, straddling belonging and not belonging. This conflict can be seen in a response to detention that, while not unique to members of this group, was highly pronounced and took on specific expressions for the men that I interviewed: non-compliance with the rules of detention and deportation. One common form of non-compliance I observed was that participants often assisted others with their bail and immigration cases. In contrast to depictions of hypermasculine detainee violence and conflict (see Bosworth 2014: 183), participants described the role that they played using their knowledge of "the system" and the English language to provide compassionate support to others, which gave them purpose and relief from their othered subjectivities. This often led to participants being labeled by IRC and Home Office staff as "troublemakers.” In Lee's words:

You play the role of helping in detention because you know how things work. Welfare, lawyer, medicine ... I could relate and speak English.... It makes you feel freedom within yourself, that you can make a change in someone's life.... When they realized I was helping people, they started moving me to different centers. They come for me at night. To stress you out.

Bolstered by feelings that they were entitled to certain rights that they had previously understood as universal when growing up in Britain, participants indicated that they often engaged in another common form of non-compliance-explicitly challenging staff whom they saw as acting in unjust, disrespectful or discriminatory ways. Suleymann, for example, would "step in and say something when [officers] abuse[d] their authority." Other participants reported frequent participation in collective protests against conditions inside IRCs. They often justified these individual and collective protests in terms of values that signify "good citizens" in Britain, such as fairness, free speech and human rights (B. Anderson 2013). As such, these acts can be seen as attempts to challenge alterity.

A third form of non-compliance, shared among most participants, was to resist deportation. Going beyond common forms of resistance, such as refusing to sign documents or meet with embassy officials, two participants successfully halted their deportation flights in ways that were possible only because of their claims to British identity. While Coco-G escaped deportation by persuading the pilot that he was English and could not understand the travel documents issued in French, Suleymaan told me, in a typical London accent, that:

They put me on a plane. One of the officers was a black guy from Bermondseywhere I'm from. I said, "What's the difference between me and you? We speak and act the same. Are you gonna come to Mogadishu too?" ... I stopped the flight by 
talking to the passengers. I said, "this is illegal, please record this on your phones. I'm not willingly on this plane." ... People were shocked.

While these acts complicate the process of "becoming an immigrant," they also increase the already long stints in detention that people in this group experience. Non-compliance was often used by the Home Office to justify transfers to other IRCs that disrupted support networks, to dispute bail claims, and to argue that participants carried a high risk of harm to the public. As a result, men who grew up in the UK spend considerable periods of time in detention-usually more than a year among my participants compared to an average of three months for the total IRC population (Shaw 2018: 26), with one participant spending a staggering total of five years in detention. Because people in this group are likely to have close family bonds in the UK, prolonged detention puts intense strains on relationships, often leading to the breakdown of supportive partnerships and estrangement from families. For my participants, the sense of failure that this caused, as well as isolation resulting from being cut off from support networks, tended to aggravate already existing mental health problems rooted in the traumatic backgrounds of participants that contributed to their becoming detainable in the first place. Several men reported self-harm, suicide attempts, dissociative episodes and panic attacks as their indefinite incarceration progressed. Biographical ruptures thus became psychological breakdowns, exasperated by the ever-present threat of deportation.

Turnbull and Hasselberg (2017) have shown that detention is experienced as an unfair "double punishment" for former prisoners that brings specific challenges and distresses that prison sentences do not. Bosworth $(2019 \mathrm{a}, \mathrm{b})$ has argued that detention shifts justification for punishment from culpability to identity, itself mediated though gender, legal status and race. Indeed, as well as a general sense that detention was illegitimate and "against human rights" (according to Anthony), given that prison sentences had been served already, the harms of detention were felt as punitive attempts by the state to discipline foreignness and "break you physically, mentally, spiritually" (Coco-G) until participants accepted their otherness by complying with deportation. For my participants, deportation was inconceivable, and the threat of being "returned" to unfamiliar places compounded its harmful and punitive effects.

In addition to well-founded fears of facing poverty, persecution and violence that some had fled as children, the men I interviewed usually had few connections to and little knowledge or memory of the places to which they might be deported. Faced with removal to Somalia, Suleymaan told me that he knew "no more about that place than you do." For OJ, who had only recently left school, deportation to Poland, where he had no friends or family and thus would be "completely stuck," was his "worst nightmare." As with other interlocutors, for Christopher, who was born in the UK to Jamaican parents who did not have settled immigration status and whose application for citizenship was never finalized when he was a child, deportation felt impossible and dangerous:

They're trying to send me somewhere I don't know.... I've never been to Jamaica....

I've never even been on a plane before.... I can't really imagine [life after deportation] .... People die in Jamaica left, right and center.

Although life after deportation was unimaginable, the prospect of being placed on a plane and taken from their lives in Britain permanently — and at any moment-plagued participants constantly. This brought the experience of deportation into everyday life in detention-in a process marked by confusion and fear that Griffiths (2014) has called "temporal uncertainty." Furthermore, the damage that deportation represents to gendered roles as 
emotionally and materially supportive fathers and partners, brothers and sons, was viewed as having the potential to "break families" (Coco-G) and this became an intense source of stress. Although the Home Office argued (in decision letters to Anthony and Lee) that there was "nothing to prevent" families from visiting deportees and that "normal adult relationships" could be maintained via telephone, email and Skype (see also Grant et al. 2015), men pointed out that their loved ones would not be able to visit and ridiculed the idea that they could fulfill family responsibilities remotely:

[Deportation would mean] complete family breakdown. I would never see my child. They couldn't afford to fly to me, and I couldn't come home.... My relationship with my partner would definitely end.... They say I can keep a relationship over Skype....

I'd like to see them do it with their kids. [Anthony]

While some participants argued that that these assertions demonstrated the undervaluing of fatherhood by the state and placed their British BAME children at risk of future criminalization in the absence of responsible male role models, others expressed the prospect of deportation in explicitly gendered terms. For Lee, thirty-four years of age, who arrived in the UK when he was six, returning to the Democratic Republic of Congo would mean emasculation and exclusion from male adulthood:

Over there they'll feel like you've not taken responsibility because you don't own a house here, you were over there and now you're here, you came with nothing. They wouldn't understand what you've been through or what's happened. You won't have that authority to say whatever you want to say or be a man.... These old guys will think ... he's a grown man but he's still a child.

The ever-present threat of deportation that detention generates, therefore, becomes a challenge to men's gendered subjectivities. In comparison with more recent arrivals, this challenge is more acute for men who were raised in Britain because they are likely to have deeply-embedded positions within settled family networks, and because these subjectivities are formed around cultural constructions of gender specific to Britain (see also Bosworth and Kellezi 2014).

In sum, men who grew up in the UK commonly respond to detention by refusing to comply with the deportation regime in ways particular to this group, fueled by conceptions of rights and values tied to their British upbringings and facilitated by their understanding of British institutions. While resisting and problematizing identity transformations, noncompliance tends to intensify the harms of detention, which include extended incarceration and isolation from support networks, heightening the punitive effects of detention-seen as an attempt to "break" detainees so that they accept their foreignness and comply with deportation. Furthermore, the prospect of "return" becomes an ever-present source of gendered harm that was unimaginable yet threatened to permanently sever their connections to Britishness and result in them being irredeemably othered.

\section{Conclusion}

In most detention centers in the $\mathrm{UK}$, there exists a group of people who, to varying degrees, perceive themselves, and are perceived by fellow detainees and staff, as British. They arrived in the UK as children, have spent time in the British education system and often have extensive networks of family and friends in the UK. None of them ever acquired 
British citizenship, although many were unaware of this until contact with the criminal justice system triggered a revocation of their immigration status, rendering them detainable and deportable. Despite similar life trajectories to their British peers who run afoul of the law-and whose interactions with the police often involve classed, gendered and racialized dynamics, as well as unaddressed childhood trauma and sometimes inadequate care by local authorities - when individuals, such as my participants, encounter the criminal justice system, they are treated as "foreign criminals." Rather than being released and reintegrated after serving their sentences, they are transferred to immigration detention as the state tries to deport them to places to which they have little or no ties; in many cases, they have never visited the place to which they are being deported and, more often than not, do not speak the language of their purported "home." Building on important recent literature on racialization, illegality, criminalization and border controls, as well as that on belonging, citizenship and the demonization of FNOs, this article has shown that immigration detention and the production of detainability are characterized by unique forms of harm for people who grew up in Britain.

Challenging a deep sense of belonging to Britain that binds and shapes the behavior of this group in IRCs in relation to other detainees and staff, those in detention experience it as a profound rupture in the life course, causing shock, confusion and eventually an uneasy reshaping of identity - a new identity that reflects the feeling of simultaneously belonging and not belonging. Men who grew up in the UK experience, in other words, a partial transition from "good citizens" to culturally-denationalized and unwanted migrants. They respond to this transition with acts of non-compliance possible only because of their claims to Britishness, which question the boundaries between citizen and foreign criminal. Yet, this resistance can prolong periods of detention, thereby damaging close relationships, causing isolation, and compounding mental health issues that are inextricably intertwined with their immigration histories. Detention is experienced as a "double punishment" and an attempt to break detainees until they accept deportation and immigrant status. This ever-present yet inconceivable possibility of deportation, however, becomes a source of gendered harm that threatens to sever permanently their ties to Britishness and turn them irrevocably into unwanted migrants.

This article contributes to theoretical understandings of border control, citizenship and penality, as well as the relationships between them, by demonstrating how national belonging is constructed through a dispersed state apparatus including the criminal justice, education, health care and housing systems. This article has also illuminated how "Britishness" is related to internal processes of identity formation that are tied to class, gender and race, in addition to immigration histories and the experience of immigration detention. Despite socialization into the values, rights and institutions that enable the general population to make claims on citizenship, some who are born or arrive in the UK as children are funneled toward incarceration and potential deportation in a process that renders legitimate claims to citizenship impossible, revealing the classed, gendered and raced contingencies of belonging and the dire personal implications of denationalization. Rather than acknowledging the role of the state in creating deportability through its policies and practices, the British state attempts to banish its "homegrown criminals" and, in so doing, constructs them as demonized foreign criminals - in contrast to mythical "good citizens." It is high time that the UK took responsibility for the way that it fails children who grow up within its borders rather than harming them further as adults in detention centers.

Acknowledgments This research was funded by the Economic and Social Research Council [Grant Number 1653375]. 
Open Access This article is licensed under a Creative Commons Attribution 4.0 International License, which permits use, sharing, adaptation, distribution and reproduction in any medium or format, as long as you give appropriate credit to the original author(s) and the source, provide a link to the Creative Commons licence, and indicate if changes were made. The images or other third party material in this article are included in the article's Creative Commons licence, unless indicated otherwise in a credit line to the material. If material is not included in the article's Creative Commons licence and your intended use is not permitted by statutory regulation or exceeds the permitted use, you will need to obtain permission directly from the copyright holder. To view a copy of this licence, visit http://creativecommons.org/licenses/by/4.0/.

\section{References}

Allen, B. (2008). An analysis of the impact of diverse forms of childhood psychological maltreatment on emotional adjustment in early adulthood. Child Maltreat, 13(3), 307-312. https://doi. org/10.1177/1077559508318394.

Anderson, B. R. O. (1983). Imagined communities: Reflections on the origin and spread of nationalism. London: Verso.

Anderson, B. (2013). Us and them? The dangerous politics of immigration control. Oxford: Oxford University Press.

Anderson, B., Beinart, S., Farrington, D., Langman, J., Sturgis, P., \& Utting, D. (2005). Risk and protective factors. London: Youth Justice Board for England and Wales.

Athwal, H. (2015). "I don't have a life to live": Deaths and UK detention. Race and Class, 56(3), 50-68. https://doi.org/10.1177/0306396814556224.

Bales, K., \& Mayblin, L. (2018). Unfree labour in immigration detention: Exploitation and coercion of a captive immigrant workforce. Economy and Society, 47(2), 191-213. https://doi.org/10.1080/03085 147.2018.1484051.

Bhui, H. S. (2007). Alien experience: Foreign national prisoners after the deportation crisis. Probation Journal, 54(4), 368-382. https://doi.org/10.1177/0264550507083536.

Bhui, H. S. (2016). The place of "race" in understanding immigration control and the detention of foreign nationals. Criminology and Criminal Justice, 16(3), 267-285. https://doi.org/10.1177/17488 95816646613.

Boe, C. S. (2016). From banlieue youth to undocumented migrant: Illegalized foreign-nationals in penal institutions and public space. Criminology and Criminal Justice, 16(3), 319-336. https://doi. org/10.1177/1748895816650480.

Bosworth, M. (2014). Inside immigration detention. Abingdon, Oxon, UK: Routledge.

Bosworth, M. (2019a). Affect and authority in immigration detention. Punishment \& Society, 21(5), 542-559. https://doi.org/10.1177/1462474518803321.

Bosworth, M. (2019b). Immigration detention, punishment and the transformation of justice. Social \& Legal Studies, 28(1), 81-99. https://doi.org/10.1177/0964663917747341.

Bosworth, M., \& Kellezi, B. (2014). Citizenship and belonging in a women's immigration detention centre. In C. Phillips \& C. Webster (Eds.), New directions in race, ethnicity and crime (pp. 80-96). Abingdon, Oxon: Routledge.

Bosworth, M., \& Slade, G. (2014). In search of recognition: Gender and staff-detainee relations in a British immigration removal centre. Punishment \& Society, 16(2), 169-186. https://doi. org/10.1177/1462474513517017.

Bowling, B., \& Westenra, S. (2020). "A really hostile environment": Adiaphorization, global policing and the crimmigration control system. Theoretical Criminology, 24(2), 163-183. https://doi. org/10.1177/1362480618774034.

Cape-Davenhill, L. (2015). Cutting justice: The impacts of the legal aid cuts for people detained in brook house and tinsley house IRCs. Crawley, UK: Gatwick Detainees Welfare Group.

Cornelisse, G. (2010). Immigration detention and the territoriality of universal rights. In N. De Genova $\&$ N. Peutz (Eds.), The deportation regime: Sovereignty, space, and the freedom of movement (pp. 101-122). Durham, NC: Duke University Press.

de Noronha, L. (2019). Deportation, racism and multi-status Britain: Immigration control and the production of race in the present. Ethnic and Racial Studies, 42(14), 2413-2430. https://doi. org/10.1080/01419870.2019.1585559.

Detained Voices (2018) The Strikers' Demands [online], London, UK. Retrieved February 20, 2019, from https://detainedvoices.com/2018/02/25/the-strikers-demands/. 
Dorling, K. (2013). Growing up in a hostile environment: The rights of undocumented migrant children in the UK. Colchester, Essex, UK: Coram Children's Legal Centre.

Garin, E., Beise, J., Hug, L., \& You, D. (2016). Uprooted: The growing crisis for refugee and migrant children. New York: United Nations Children's Fund.

Gibney, M. J. (2020). Denationalisation and discrimination. Journal of Ethnic and Migration Studies, 46(12), 2551-2568.

Godshaw, D. (2017). Don't dump me in a foreign land: Immigration detention and young arrivers. Crawley, UK: Gatwick Detainees Welfare Group.

Grant, S., Kofman, E., Peel, C., \& Wray, H. (2015). Skype families: The effects on children of being separated from a mum or dad because of recent immigration rules. London: Children's Commissioner for England, Middlesex University, Joint Council for the Welfare of Immigrants.

Griffiths, M. (2013). Living with uncertainty: Indefinite immigration detention. Journal of Legal Anthropology, 1(3), 263-286. https://doi.org/10.3167/jla.2013.010301.

Griffiths, M. (2014). Out of time: The temporal uncertainties of refused asylum seekers and immigration detainees. Journal of Ethnic and Migration Studies, 40(12), 1991-2009. https://doi. org/10.1080/1369183X.2014.907737.

Griffiths, M. (2017). Foreign, criminal: A doubly damned modern British folk-devil. Citizenship Studies, 21(5), 527-546. https://doi.org/10.1080/13621025.2017.1328486.

Hall, A. (2012). Border watch: Cultures of immigration, detention and control. London: Pluto.

Haque, Z. (2019) Britain deports people who grew up here. This racialised system must end. The Guardian, Opinion: Immigration and Asylum. London. Retrieved February 20, 2019, from https://www. theguardian.com/commentisfree/2019/feb/11/britain-deports-people-racialised-system-citizenship.

Hayden, C. (2010). Offending behaviour in care: Is children's residential care a "criminogenic" environment? Child and Family Social Work, 15(4), 461-472. https://doi.org/10.111 1/j.1365-2206.2010.00697.x.

Hugman, R., Pittaway, E., \& Bartolomei, L. (2011). When "do no harm" is not enough: The ethics of research with refugees and other vulnerable groups. The British Journal of Social Work, 41(7), 1271-1287. https://doi.org/10.1093/bjsw/bcr013.

Isin, E. F., \& Nielson, G. M. (Eds.). (2008). Acts of citizenship. London: Zed Books.

Keating, F., \& Robertson, D. (2004). Fear, black people and mental illness: A vicious circle? Health and Social Care in the Community, 12(5), 439-447. https://doi.org/10.1111/j.1365-2524.2004.00506.x.

Lammy, D. (2017). The lammy review: An independent review into the treatment of, and outcomes for, black, Asian and minority ethnic individuals in the criminal justice system. London: Lammy Review.

Neale, D. (2012). "A prison in the mind": The mental health implications of detention in brook house immigration removal centre. Crawley, UK: Gatwick Detainees Welfare Group.

Parliament, House of Commons (2019) Notices of amendments given up to and including Thursday 20 June 2019: Immigration and Social Security Co-Ordination (EU Withdrawal) Bill, London: House of Commons.

Parmar, A. (2018). Policing belonging: Race and nation in the UK. In M. Bosworth, A. Parmar, \& Y. Vázquez (Eds.), Race, criminal justice, and migration control: Enforcing the boundaries of belonging (pp. 108-124). Oxford: Oxford University Press.

Phelps, J., Abdal Du Preez, B., Hamid, K., Carette, M., Matthew, S., \& Souleymane, (2014). The state of detention: Immigration detention in the UK in 2014. London: Detention Action.

Phillips, C., \& Bowling, B. (2017). Ethnicities, racism, crime, and criminal justice. In A. Liebling, S. Maruna, \& L. McAra (Eds.), The Oxford handbook of criminology (6th ed., pp. 190-212). Oxford: Oxford University Press.

Plomin, J. [Director]. (2017). Undercover: Britain's immigration secrets [television series episode]. In Wightman, K [Executive producer], Panorama. London: British Broadcasting Company.

Project for the Registration of Children as British Citizens (PRCBC) (2017) Briefing for parliamentarians on home office fees for children registering as British citizens. London. Retrieved February 20, 2019, from https://prcbc.files.wordpress.com/2015/08/briefing-on-fees1.pdf.

Project for the Registration of Children as British Citizens (PRCBC) (2019) Briefing: Children's rights to British citizenship blocked by good character requirement. London. Retrieved December 5, 2019, from https://prcbc.files.wordpress.com/2019/10/joint_summary-on-good-character-requi rement-in-childrens-citizenship-rights.pdf.

Sands, C. (2016). Criminal care: Children's homes and criminalising children. London: The Howard League for Penal Reform.

Shaw, S. (2016). Review into the welfare in detention of vulnerable persons: A report to the Home Office. London: Secretary of State for the Home Department. 
Shaw, S. (2018). Assessment of government progress in implementing the report on the welfare in detention of vulnerable persons: A follow-up report to the Home Offce by Stephen Shaw. London: Secretary of State for the Home Department.

Staines, J. (2017). Looked after children and youth justice: A response to recent reviews. Safer Communities, 16(3), 102-111. https://doi.org/10.1108/sc-01-2017-0005.

Tsangarides, N. (2012). "The second torture”: The immigration detention of torture survivors. London: Medical Justice.

Turnbull, S., \& Hasselberg, I. (2017). From prison to detention: The carceral trajectories of foreignnational prisoners in the United Kingdom. Punishment \& Society, 19(2), 135-154. https://doi. org/10.1177/1462474516660695.

Tyler, I. (2013). Naked protest: The maternal politics of citizenship and revolt. Citizenship Studies, 17(2), 211-226. https://doi.org/10.1080/13621025.2013.780742.

Walters, W. (2002). Deportation, expulsion and the international police of aliens. Citizenship Studies, 6(3), 265-292. https://doi.org/10.1080/1362102022000011612.

Wilding, J., \& Dembour, M.-B. (2015). Whose best interests? Exploring unaccompanied minors' rights through the lens of migration and asylum processes (MinAs): The UK National Report. Brighton, UK: University of Brighton.

Publisher's Note Springer Nature remains neutral with regard to jurisdictional claims in published maps and institutional affiliations. 